\title{
Host preference of the hemiparasite Struthanthus flexicaulis (Loranthaceae) in ironstone outcrop plant communities, southeast Brazil
}

\author{
Fabiana Alves Mourão ${ }^{1 *}$, Rafael Barros Pereira Pinheiro', Claudia Maria Jacobi' and José Eugênio Côrtes Figueira'
}

Received: July 8, 2015

Accepted: October 14, 2015

\begin{abstract}
Struthanthus flexicaulis is a hemiparasite abundant in ironstone outcrops in southeast Brazil. We evaluated its host preference among species of the plant community, taking into account the abundance and foliage cover of the hosts. The importance of each species in the community and the mortality caused by the parasite were assessed based on a quantitative survey in 10 strips measuring $1 \mathrm{~m} \times 50 \mathrm{~m}$. The 10,290 individuals belonged to 42 species. Only 15 had a relative abundance in the plant community greater than $1 \%$, of which 12 showed vestiges of parasitism. More than $80 \%$ of deaths in the community were associated with parasitism. Non-infected individuals had significantly less mortality rates $(7 \%)$ than those infected $(83 \%)\left(\chi^{2}=1102.4, \mathrm{df}=1\right.$, $\mathrm{p}<0.001)$. The observed infestation was different from the expected both regarding relative host abundance $\left(\chi^{2}=714.2, \mathrm{df}=11\right.$, $\mathrm{p}<0.001)$ and foliage cover $\left(\chi^{2}=209.2, \mathrm{df}=11, \mathrm{p}<0.001\right)$. Struthanthus flexicaulis preferred Mimosa calodendron, a legume attractive to avian seed dispersers. The interaction is maintained and intensified not only by the birds, who deposit innumerous seeds on the hosts branches, but also very likely by the ability of $M$. calodendron to fix nitrogen, thereby enhancing the mistletoe's development.
\end{abstract}

Keywords: canga, Iron Quadrangle, ironstone outcrop, plant-plant interaction, parasitism

\section{Introduction}

Parasitic plants depend on their hosts for nutrient and water supply, and may show different degrees of specificity for their hosts. This preference is related to the local abundance and degree of constancy of plants in time and space (Norton \& Carpenter 1998; Norton \& Lange 1999). Besides resource availability (plants), the success of infection also depends on anatomic and chemical aspects that promote host recognition and haustorium formation, a modified root specialized in nutrient uptake (Rodl \& Ward 2002; Press \& Phoenix 2005; Arruda et al. 2006).

Specificity may be advantageous in homogeneous environments, where a certain plant species is predominant. In these cases, specialist parasites could increase their efficiency in nutrient uptake from their hosts. In New Zealand, the mistletoes Alepis flavida, Peraxilla colensoi, and P. tetrapetala specialize in different Nothofagus species (Norton \& Carpenter 1998). However, in heterogeneous environments, specialists would be in disadvantage because of the high plant diversity (Norton \& Carpenter 1998; Arruda et al. 2006), especially when potential hosts occur in low densities. This would explain the low specificity of species of Loranthaceae in heterogeneous plant communities such as tropical rainforests (Norton \& Carpenter 1998) and savannas (Dzerefos et al. 2003; Arruda et al. 2006).

The impact caused by mistletoe infection on a plant community may vary as a function of the host plant identity and abundance. Legumes appear to be preferred hosts of all parasitic plants on account of their nitrogen-fixation

\footnotetext{
${ }^{1}$ Departamento de Biologia Geral, Instituto de Ciências Biológicas, Universidade Federal de Minas Gerais, Av. Antônio Carlos, 6627, 31270-901, Belo Horizonte, MG, Brazil

* Corresponding author: fabimourao@gmail.com
} 
ability (Radomiljac et al. 1999; Bowie \& Ward 2004). The term 'preference' has been used in several works to indicate the disproportional infection in relation to host availability in the area (Aukema \& Río 2002; Dzerefos et al. 2003; Press \& Phoenix 2005; Runyon et al. 2006; Lemaitre et al. 2012). The main factors that lead to this preference are the host spatio-temporal distribution, behavior of avian dispersers, and parasite establishment success (Aukema \& Rio 2002; Medel et al. 2002; Roxburgh \& Nicolson 2005).

Struthanthus flexicaulis is a common hemiparasite on plant communities over ironstone outcrops in the Iron Quadrangle region (southeast Brazil), and is known to cause a significant reduction on the survival and fitness of its hosts (Mourão et al. 2009). In these communities it successfully infects more than 40 plant species (Mourão et al. 2006), although probably with different degrees of success among these hosts, based on the preference factors mentioned above. Previous studies suggested that the shrub Mimosa calodendron (Fabaceae) is its preferred host (Mourão et al. 2009; Reis et al. 2010). However, since this species is one of the most abundant on ironstone outcrops in the Iron Quadrangle, this perception needs to be validated by a rigorous comparison among hosts. In this study we evaluated the preference of $S$. flexicaulis to hosts in the plant community based on their abundance and cover, and the effect of parasitism on the mortality rate of each host species. Our hypothesis was that M. calodendron is a preferred perching species for birds dispersing $S$. flexicaulis seeds and, being a legume, a better host for their survival and also a more resistant host to parasitism. We predicted that M. calodendron individuals are significantly more infected than other hosts but less prone to death by parasitism.

\section{Materials and Methods}

We performed our survey in a plant community over ironstone outcrop $\left(20^{\circ} 03^{\prime} 60^{\prime \prime} \mathrm{S}, 44^{\circ} 02^{\prime} 00^{\prime \prime} \mathrm{W}, 1300 \mathrm{~m}\right)$, within the limits of the Serra do Rola Moça State Park, a strictly protected area located in the Iron Quadrangle, southern Espinhaço Range. The climates is mesothermic, with mean annual rainfall between 1000 and $1500 \mathrm{~mm}$, a pronounced dry season between April and September, and mean annual temperature of $25^{\circ} \mathrm{C}$ (Rizzini 1997).

The plant communities established on these outcrops are species-rich and are home to members of $45 \%$ of the native vascular families that occur in Brazil, including until now 60 endemic species (Carmo \& Jacobi 2012). Individuals are subjected to high radiation, poorly developed soils (litholic neosols) with high heavy metals concentrations, and low water retention (Porto \& Silva 1989; Teixeira \& Lemos-Filho 2002; Jacobi et al. 2007). Given these conditions, vegetation is predominantly composed of herbs and shrubs, with few tree species. Species-rich dicotyledon families are Asteraceae, Fabaceae and Myrtaceae; and the main monocotyledons are Poaceae, Cyperaceae and Orchidaceae (Jacobi et al. 2007; Viana \& Lombardi 2007). Among parasitic plants, the genera Tripodanthus and Struthanthus are very abundant, both belonging to Loranthaceae, the largest mistletoe family.

To evaluate the importance of each species in the community and mortality rates associated to parasitism, we performed a quantitative survey along ten parallel strips $(1 \mathrm{~m} \times 50 \mathrm{~m})$, distant $10 \mathrm{~m}$ between each other, totaling $500 \mathrm{~m}^{2}$. Each strip was divided into $1 \mathrm{~m}^{2}$ plots and individuals within them were counted and identified. Because of the difficulty of calculating their abundance, Poaceae, Cyperaceae, and Orchidaceae were excluded from the analyses. Members of these families are seldom -if everhosts for Loranthaceae, so analyses were not affected by their exclusion.

In both the analyses of mortality and preference, we only took into account the twelve species with relative abundance $>1 \%$ in the sampled area and at least one infected individual. Individuals were separated into four categories, combining two binary characteristics: alive or dead, and infected or not. This classification was possible because dry branches and haustoria of $S$. flexicaulis remained clearly visible on dead infected individuals. We used Chi-square tests to test for significant mortality differences between infected and non-infected individuals of each species.

To quantify the abundance of each plant species in the sampled area we considered all individuals. Species with clonal growth, such as Cactaceae and Velloziaceae, were counted as one individual when distance between ramets was less than $5 \mathrm{~cm}$. For this reason the exact number of individuals is probably overestimated in these families. Plant cover of each individual was estimated based on the vertical crown projection to the ground. These areas were calculated by approximating them to regular geometric figures.

To calculate the expected number of infected individuals based on their relative abundance we used the equation:

$$
P_{\exp }=\frac{n_{i}}{n_{\text {tot }}} \times P_{\text {tot }}
$$

where $\mathrm{P}_{\exp }=$ number of expected individuals of each host species, $\mathrm{n}_{\mathrm{i}}=$ abundance of each host species, $\mathrm{n}_{\text {tot }}=$ total number of sampled individuals, and $\mathrm{P}_{\text {tot }}=$ total number of infected individuals.

Similarly, the following equation was used for the expected number of infected individuals based on plant cover, substituting variables as follows:

$$
P_{\exp }=\frac{\operatorname{cov}_{i}}{\operatorname{cov}_{\text {tot }}} \times P_{\text {tot }}
$$

where $\operatorname{cov}_{\mathrm{i}}=$ plant cover of each host species and $\operatorname{cov}_{\text {tot }}=$ total plant cover of infected individuals. 
In both cases, we performed Chi-square tests to check if the observed distribution differed from the expected distribution, whereby a small departure from the expected indicates lack of preference.

\section{Results}

The 10,290 individuals in the sampled area belonged to 24 families and 42 species (Tab. S1 in supplementary material). The more frequent families were Asteraceae (eight spp.), Melastomataceae (five spp.), and Velloziaceae and Orchidaceae (four spp. each). The four more abundant species were Cattleya caulescens (Orchidaceae, 1491 ind.), Microstachys daphnoides (Euphorbiaceae, 1130 ind.), M. calodendron (Fabaceae, 858 ind.) and Lychnophora pinaster (Asteraceae, 806 ind.).

Fifteen species had a relative abundance $>1 \%$ in the community, of which 12 had signs of parasitism (Tab. 1). The most infected species were the shrubby eudicots $M$. calodendron and L. pinaster. The monocots Cattleya caulescens, Acianthera teres and Vellozia graminea had no infected individuals. The proportion of non-infected dead plants $(7 \%)$ was significantly lower than that of infected individuals (83\%) $\left(\chi^{2}=1102.4, \mathrm{df}=1, \mathrm{p}<0.001\right)$. Overall, more than $80 \%$ of deaths among individuals of the 12 host species analysed were related to parasitism. However, the number of dead infected individuals varied considerably among hosts. For instance, of 164 dead plants of M. calodendron, 139 showed mistletoe vestiges, while M. daphnoides, one of the most abundant species, had only one dead infected individual (Tab. 1). Mimosa calodendron had a much larger proportion of dead individuals than the other hosts, and this was strongly associated with infection by $S$. flexicaulis.

The observed frequency of infected hosts was different from the expected, both using abundance $\left(\chi^{2}=714.2\right.$, $\mathrm{df}=11, \mathrm{p}<0.001)$ and plant cover $\left(\chi^{2}=209.2, \mathrm{df}=11\right.$, $\mathrm{p}<0.001)$. Not all hosts contributed equally to this outcome. Regarding relative abundance, most of the observed infected proportions were close to the expected values, with notable exceptions: $M$. calodendron was infected $249 \%$ more than expected, whereas M. daphnoides and T. heteromalla were, respectively, $64 \%$ and $68 \%$ less infected than expected (Fig. 1). These 'preference' results differed from those of relative cover, due to the size of individual plants, even within a single species. Consequently, when host cover was used, the number of infected $M$. daphnoides and T. heteromalla was very close to the expected, M. calodendron was $89 \%$ more infected, and L. pinaster was $55 \%$ less parasitized than expected (Fig. 2).

\section{Discussion}

The preference of $S$. flexicaulis for M. calodendron was evident. The fact that $M$. calodendron was among the most abundant and also occupied the largest cover in the community indicates dominance over the other species. Being a legume growing in a nutrient-poor environment, this species has advantage as a competitor. It was therefore expected that, if only by its relative abundance, a large number of $M$. calodendron plants would be infected. Comparison with other hosts, however, showed that the association between both species goes beyond how well represented the legume is in the community.

Table 1. Species with relative abundance above $1 \%$ and parasitized. Columns represent the number of individuals in each category: not parasitized (NP) or parasitized (P), dead or alive. Species were ranked according to decreasing abundance values. Cattleya caulescens, Acianthera teres (Orchidaceae), and Vellozia graminea (Velloziaceae) had relative abundance $>1 \%$ in the plant community but were excluded from this list because they did not have parasitized individuals.

\begin{tabular}{|l|c|c|c|c|}
\hline \multirow{2}{*}{ Species } & \multicolumn{3}{|c|}{ Live } & \multicolumn{2}{c|}{ Dead } \\
\cline { 2 - 5 } & NP & P & NP & P \\
\hline Microstachys daphnoides & 1106 & 26 & 3 & 1 \\
\hline Mimosa calodendron & 542 & 164 & 13 & 139 \\
\hline Lychnophora pinaster & 696 & 97 & 7 & 6 \\
\hline Tibouchina heteromalla & 726 & 24 & 0 & 0 \\
\hline Stachytarpheta glabra & 357 & 24 & 0 & 1 \\
\hline Symphyopappus brasiliensis & 363 & 4 & 1 & 0 \\
\hline Vellozia compacta & 282 & 14 & 0 & 1 \\
\hline Eriope macrostachya & 185 & 16 & 0 & 1 \\
\hline Borreria capitata & 195 & 5 & 0 & 0 \\
\hline Baccharis reticularia & 132 & 26 & 5 & 4 \\
\hline Croton serratoideus & 133 & 1 & 1 & 0 \\
\hline Chromolaena multiflosculosa & 89 & 1 & 0 & 0 \\
\hline Total & 4806 & 402 & 30 & 153 \\
\hline
\end{tabular}




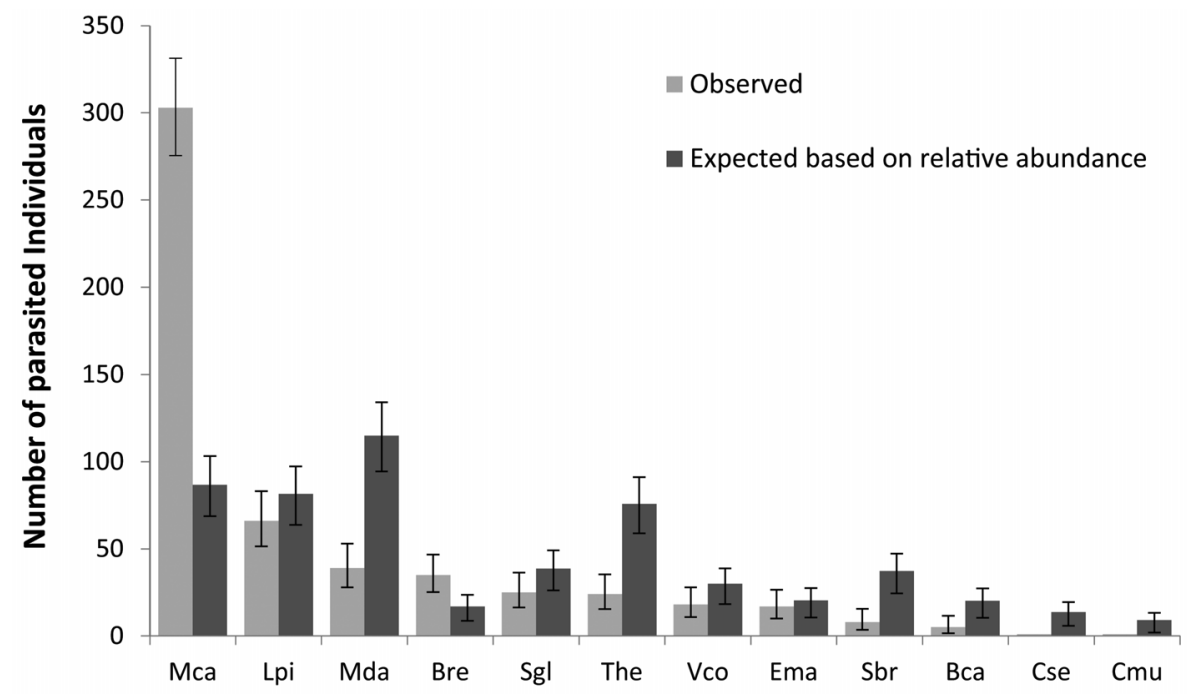

Figure 1. Expected and observed parasitism based on the relative abundance of each species. Bars are the $95 \% \mathrm{CI}$. Bca $=$ Borreria capitata; Bre $=$ Baccharis reticularia $; \mathrm{Cmu}=$ Chromolaena multiflosculosa $; \mathrm{Cse}=$ Croton serratoideus; $\mathrm{Ema}=$ Eriope macrostachya $;$ Lpi $=$ Lychnophora pinaster $; \mathrm{Mca}=$ Mimosa calodendron; $\mathrm{Mda}=$ Microstachys daphnoides; Sbr = Symphyopappus brasiliensis; Sgl = Stachytarpheta glabra; The = Tibouchina heteromalla; Vco = Vellozia compacta .

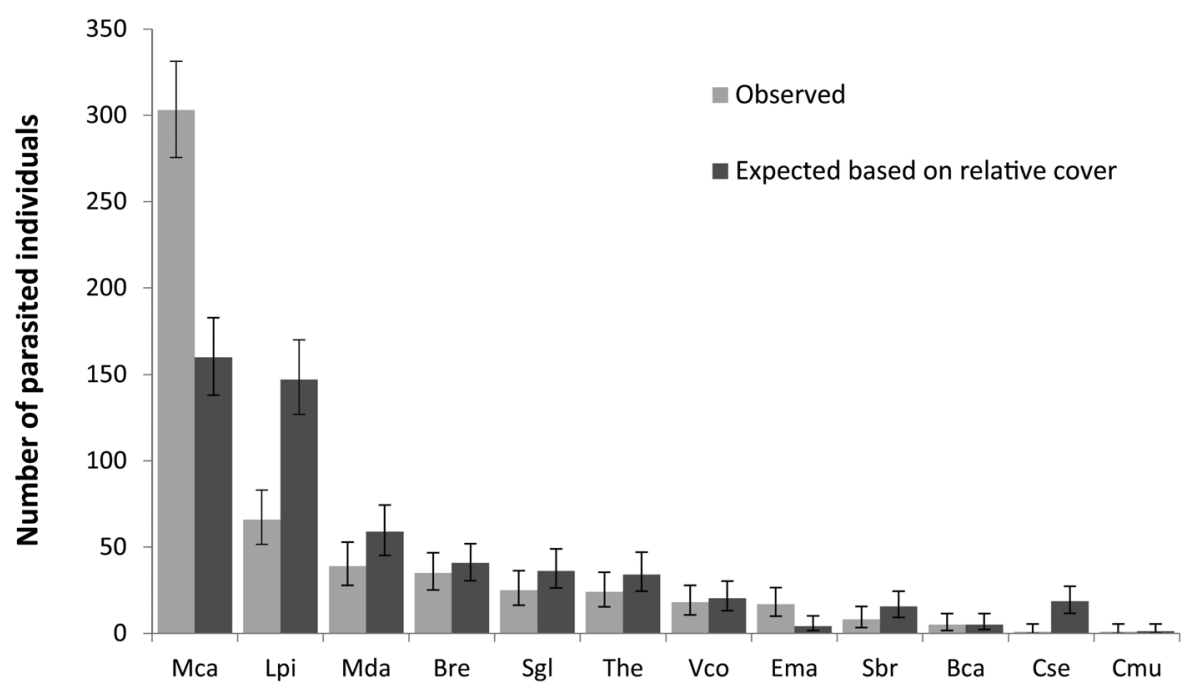

Figure 2. Expected and observed parasitism based on the relative cover of each species. Bars are the $95 \%$ CI. Bca = Borreria capitata; Bre = Baccharis reticularia; $\mathrm{Cmu}=$ Chromolaena multiflosculosa; Cse = Croton serratoideus; Ema = Eriope macrostachya $;$ Lpi = Lychnophora pinaster; Mca = Mimosa calodendron; Mda = Micros tachys daphnoides; Sbr = Symphyopappus brasiliensis; Sgl = Stachytarpheta glabra; The = Tibouchina heteromalla; Vco = Vellozia compacta .

Other factors that may increase the strength of this interaction are related to the two types of dispersal that the mistletoe shows: vegetative and by birds. In the study area M. calodendron is one of the tallest shrubs and can get as high as $1.60 \mathrm{~m}$. Its hemispherical, branched crown is make this species one of the few suitable perching options for the birds that disperse the mistletoe seeds. In addition, because of its high density, the probability increases of receiving branches of the parasite coming from neighbor infected plants where they resume xylem-tapping (Mourão 2012). The vegetative dispersal is more successful when hosts are close and have a similar height (Aukema 2003; Mourão 2012).
Compared to the other 11 hosts, $M$ calodendron was much more parasitized than expected, whether estimating the infection by its abundance or cover. Lychnophora pinaster represented the only example of less infection than expected by its relative cover. This species has very flexible branches that spread across the substrate and individuals were rarely taller than $1 \mathrm{~m}$, so its architecture is not suitable for bird perching or shelter. Because birds prefer to perch on plants that rise above the others (Robinson \& Holmes 1984), only a handful of species would be more frequently visited, among which $M$. calodendron.

Mortality of the plants in the community, particularly in $M$. calodendron, was directly caused or enhanced when in 
association with $S$. flexicaulis. Contrary to our predictions, the mortality rate of infected $M$. calodendron was the highest among hosts. This suggests that besides being infected more frequently it is likely that individuals are parasitized with more intensity. A feasible explanation is that more seeds are deposited on account of more frequent bird visits. Additionally, because it is a high-quality resource, it favours the parasite's growth, as suggested by Kelly (1990).

High levels of infestation allied to edapho-climatic conditions in canga outcrops may impose a severe stress on the host, and even death (Mourão et al. 2009). Parasitic plants may inflict several types of damages to their hosts, notably leaf biomass reduction (Press \& Graves 1995; Cameron et al. 2008), usually leading to decreased photosynthetic rates (Graves et al. 1992), which may result in less flower output (Mugabe 1983). When intensely infected, M. calodendron loses from $75 \%$ to $95 \%$ of its foliage, followed by a steep reduction in the number of all reproductive structures (Mourão et al. 2009). Hence, mistletoe infection would act as a population control mechanism of $M$. calodendron, a nitrogen-fixing species with competitive advantage in environments with serious nutritional restrictions.

The evolution of host specificity in plant communities is highly correlated with the development of ecological dominance (Barlow \& Wiens 1977). Although M. calodendron is not the most abundant species in the area, it does have the largest foliage cover in the community, granting the necessary proximity for the branches of the mistletoe to reach new hosts. The marked preference of $S$. flexicaulis for this host is the result of a combination of factors of both species that increase infestation opportunities and reinforce their interaction.

\section{Acknowledgements}

Research funding was provided by the Conselho Nacional de Desenvolvimento Científico e Tecnológico (CNPq) and Fundação de Amparo à Pesquisa do estado de Minas Gerais (FAPEMIG). We thank IEF for the research and collection license, and the staff of Rola Moça State Park for logistic support. FAM thanks CNPq for her doctorate scholarship; CMJ holds a CNPq research productivity scholarship. We are also grateful for the valuable comments of two anonymous reviewers.

\section{References}

Arruda R, Carvalho LN, Del-Claro K. 2006. Host specificity of a Brazilian mistletoe, Struthanthus aff. polyanthus (Loranthaceae), in cerrado tropical savanna. Flora 201: 127-134.

Aukema JE. 2003. Vectors, viscin, and Viscaceae: mistletoes as parasites, mutualists and resources. Frontiers in Ecology and the Environment 1: 212-219.

Aukema JE, Rio CMM. 2002. Where does a fruit-eating bird deposit mistletoe seeds? Seed deposition patterns and an experiment. Ecology 83: 3489-3496.
Barlow BA, Wiens D. 1977. Host-parasite resemblance in Australian mistletoes: the case for cryptic mimicry. Evolution 31: 69-84.

Bowie M, Ward D. 2004. Water and nutrient status of the mistletoe Plicosepalus acaciae parasitic on isolated Negev Desert populations of Acacia raddiana differing in level of mortality. Journal of Arid Environments 56: 487-508.

Cameron DD, Geniez JM, Seel WE, Irving LJ. 2008. Suppression of host photosynthesis by the parasitic plant Rhinanthus minor. Annals of Botany 101: 573-578.

Carmo FF, Jacobi CM. 2012. Vascular plants on cangas. In: Jacobi CM, Carmo FF. (eds.) Diversidade florística nas cangas do Quadrilátero Ferrífero. Belo horizonte, IDM Ltda. p. 43-50.

Dzerefos CM, Witkowski ETF, Shackleton CM. 2003. Host-preference and density of woodrose-forming mistletoes (Loranthaceae) on savanna vegetation, South Africa. Plant Ecology 167: 163-177.

Graves JD, Press MC, Smith S, Stewart GR. 1992. The carbon economy of the association between cowpea and the parasitic angiosperm Striga gesnerioides. Plant, Cell and Environment 15: 283-288.

Jacobi CM, Carmo FF, Vincent RC, Stehmann JR. 2007. Plant communities on ironstones outcrops: a diverse and endangered Brazilian ecosystem. Biodiversity and Conservation 16: 2185-2200.

Kelly KC. 1990. Plant foraging: a marginal value model and coiling response in Cuscuta subinclusa. Ecology 71: 1916-1925.

Lemaitre A, Troncoso A, Niemeyer H. 2012. Host preference of a temperate mistletoe: Disproportional infection on three co-occurring host species influenced by differential success. Austral Ecology 37: 339-345.

Medel R, Botto-Mahan C, Smith-Ramírez C, et al. 2002. Historia natural cuantitativa de una relación parásito-hospedero: el sistema Tristeri$x$-cactáceas en Chile semiárido. Revista Chilena de Historia Natural 75: $127-140$.

Mourão FA. 2012. Dinâmica do forrageamento da hemiparasita Struthanthus flexicaulis Mart. (Loranthaceae) e sua influência na estrutura da comunidade vegetal de campos rupestres ferruginosos - MG. PhD Thesis, Universidade Federal de Minas Gerais, Brazil.

Mourão FA, Carmo FF, Ratton P, Jacobi CM. 2006. Hospedeiras da hemiparasita Struthanthus flexicaulis Mart. (Loranthaceae) em campos rupestres ferruginosos, Quadrilátero Ferrífero, MG. Lundiana 7: 103-110.

Mourão FA, Jacobi CM, Figueira JEC, Batista EKL. 2009. Effects of the parasitism of Struthanthus flexicaulis (Mart.) Mart. (Loranthaceae) on the fitness of Mimosa calodendron Mart. (Fabaceae), an endemic shrub from rupestrian fields over ironstone outcrops, Minas Gerais State, Brazil. Acta Botanica Brasilica 23: 820-825.

Mugabe NR. 1983. Effects of Alectra vogelli Benth on cowpea (Vigna unguiculata (L.) Walp). Some aspects on reproduction of cowpea. Zimbabwe Journal of Agricultural Research 21: 135-147.

Norton DA, Carpenter MA. 1998. Mistletoes as parasites: host specificity and speciation. Trends in Ecology and Evolution 13: 101-105.

Norton DA, Lange PJ. 1999. Host specificity in parasitic mistletoes (Loranthaceae) in New Zealand. Functional Ecology 13: 552-559.

Porto ML, Silva MFF. 1989. Tipos de vegetação metalófila em áreas da Serra de Carajás e de Minas Gerais. Acta Botanica Brasilica 3: 13-21.

Press MC, Graves JD. 1995. Parasitic plants. London, Chapman \& Hall.

Press MC, Phoenix GK. 2005. Impacts of parasitic plants on natural communities. New Phytologist 166: 737-751.

Radomiljac AM, McComb JA, Pate JS. 1999. Gas exchange and water relations of the root hemiparasite Santalum album L. in association with legume and non-legume hosts. Annals of Botany 83: 215-224.

Reis Jr FB, Simon MF, Gross E, et al. 2010. Nodulation and nitrogen fixation by Mimosa spp. in the Cerrado and Caatinga biomes of Brazil. New Phytologist 186: 934-946.

Rizzini CT. 1997. Tratado de Fitogeografia do Brasil: Aspectos Ecológicos, Sociológicos e Florísticos. 2nd. edn. Rio de Janeiro, Âmbito Cultural Edições Ltda.

Robinson SK, Holmes RT. 1984. Effects of plant species and foliage structure on foraging behavior of forest birds. The Auk 101: 672 - 684 .

Rodl T, Ward D. 2002. Host recognition in a desert mistletoe: early stages of development are influenced by substrate and host origin. Functional Ecology 16: 128-134. 
Fabiana Alves Mourão, Rafael Barros Pereira Pinheiro, Claudia Maria Jacobi and José Eugênio Côrtes Figueira

Roxburgh L, Nicolson SW. 2005. Patterns of host use in two African mistletoes: the importance of mistletoe-host compatibility and avian disperser behaviour. Functional Ecology 19: 865-873.

Runyon JB, Mescher MC, Moraes CM. 2006. Volatile chemical cues guide host location and host selection by parasitic plants. Science 313: 1964-1967.
Teixeira WA, Lemos-Filho JP. 2002. Fatores edáficos e a colonização de espécies lenhosas em uma cava de mineração de ferro em Itabirito, Minas Gerais. Revista Árvore 26: 25-33

Viana PL, Lombardi JA. 2007. Florística e caracterização dos campos rupestres sobre a canga na Serra da Calçada, Minas Gerais, Brasil. Rodriguésia 58: 159-177. 